\title{
Tectonic and geomorphic controls on the fluvial styles of the Eslida Formation, Middle Triassic, Eastern Spain
}

\author{
Alfredo Arche *, José López-Gómez \\ Instituto de Geología Económica, CSIC-UCM, Facultad de Geología, 28040 Madrid, Spain
}

\begin{abstract}
The Eslida Fm is an alluvial unit of the Buntsandstein Facies of the Iberian Ranges deposited in a half-graben basin over a period of 2-2.5 Ma during the lower Anisian (Middle Triassic). It can be subdivided into six cycles that can be correlated along the basin. The overall architecture and cyclicity were controlled by the episodic activity of the basin boundary fault. Two proximal source areas of minor importance and a distal one of major importance are identified. The petrological composition of the sandstones is arkosic to subgrauwackic, indicating source areas containing both low-metamorphic rocks and gneiss, and granitic rocks. Alluvial fans, very common in rift basins, were not developed because of slow fault scarp retreat and the lack of large antecedent rivers cutting across the rift shoulders. Paleocurrents point to the SE, except for a zone in the middle part of the basin where interference with a NE-SW fault system deflected the channels to the S. The infilling of the basin is asymmetric in a transverse section, with channel facies near the basin boundary fault to the NE and overbank facies in the distal SW part.
\end{abstract}

Keywords: asymmetric extension; fluvial styles; Iberian Basin; tectonic controls; Triassic

\section{Introduction}

The Eslida Fm, defined by López-Gómez and Arche (1993a), is the uppermost alluvial unit of the Buntsandstein Facies of the Iberian Basin, a rift basin that was formed in the Early Permian and evolved during the Mesozoic in central-eastern Iberia as part of the break-up of the Eurasian Craton, and now exposed along the alpine structure known as the Iberian Ranges (Fig. 1).

The Permian-Triassic alluvial infilling of the Iberian Basin represents the syn-rift continental period of sedimentation (López-Gómez and Arche, 1993a; Muñoz et al., 1995; Arche and
López-Gómez, 1996). It has been subdivided into three unconformity-bounded units or alloformations (López-Gómez and Arche, 1993a). From base to top these are as follows:

Unit 1: Volcanic and volcanoclastic rocks of andesitic nature followed by red beds of alluvial and lacustrine origin deposited in small, isolated semi-grabens in the NW and Central Iberian Basin with interior drainage. Its age is Early Permian (Autunian) and it comprises the Ermita and Tabarreña Fms (Pérez-Arlucea and Sopeña, 1985; López-Gómez and Arche, 1994).

Unit 2: Alluvial fan and braided river conglomerates passing into floodplain, temporary lakes and sandy braided river deposits deposited in asymmetrical grabens which are laterally interconnected with interior drainage. Its age is Late Permian 


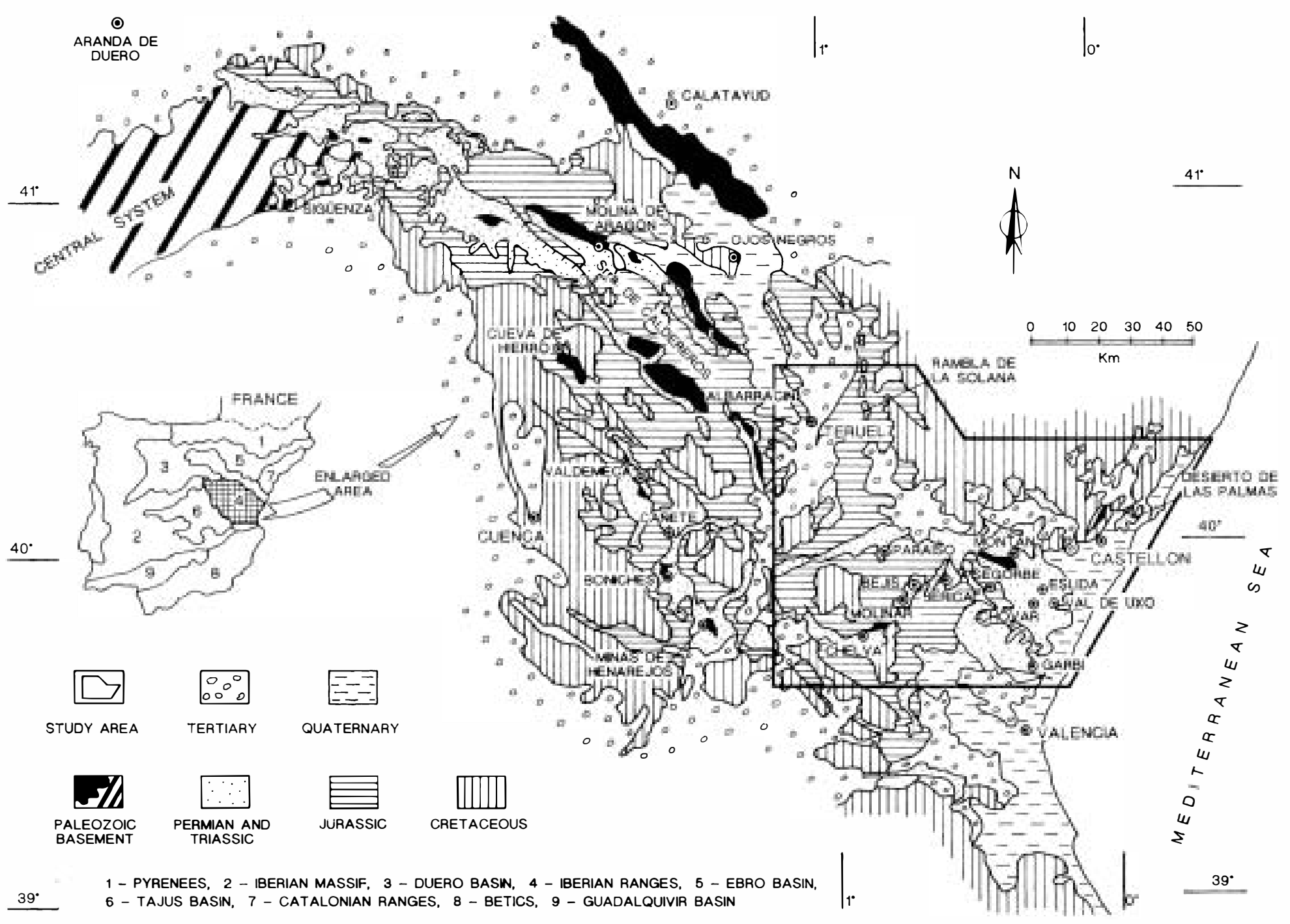

Fig. 1. Geological and geographical sketch of the Iberian Ranges and study area. 
(Thüringian) and it comprises the Montesoro, Tormón, Boniches and Alcotas Fms (Ramos, 1979; Pérez-Arlucea and Sopeña, 1985; López-Gómez and Arche, 1994).

Unit 3: Alluvial fan, sandy braided river, meandering river, floodplain and temporary lake sediments deposited in semi-grabens and symmetrical grabens open to the sea at its distal SE extreme. It is a complex and thick unit of Late Permian (Thüringian) to Middle Triassic (Anisian) age and is made up of the Hoz de Gallo, Rillo de Gallo, Prados, Arandilla, Cañizar and Eslida Fms (Ramos, 1979; Pérez-Arlucea and Sopeña, 1985; López-Gómez and Arche, 1993a).

The Eslida Fm is up to $660 \mathrm{~m}$ thick (Fig. 2) and is of lower Anisian age (Aegean-Bithynian); in spite of a total lack of biostratigraphic data for the formation, the top of the underlying Cañizar Fm has been dated as Anisian (Doubinger et al., 1990) and the overlying Muschelkalk Facies of marine origin as upper Anisian (PelsonianIllyrian) according to the ammonites and conodonts present (López-Gómez and Arche, 1993a; Márquez et al., 1994). This suggests that the Eslida Fm could have been deposited over a maximum period of $2.5 \mathrm{Ma}$, given the time span of the lower Anisian according to the recent time scale proposed by Gradstein et al. (1995) for the Triassic.

This formation consists of six superimposed composite sequences, five of which are of the coarsening-thickening type. The topmost sequence is of thickening-thinning type, reflecting the end of fluvial sedimentation as the Tethys sea started to invade the Iberian Basin from the E. Each sequence is 60 to $110 \mathrm{~m}$ thick, and displays an onlap relationship with the basement (Fig. 2). The main depocenter is in the Chovar-Eslida area and the secondary depocenter is in the Teruel area (Fig. 2). Its aerial extension is rather small in comparison with others that cover the whole Iberian Basin, although it is by far the thickest unit of the Buntsandstein Facies. It can be correlated with the Arandilla Fm to the NW but differs in fluvial style due to differences in tectonic control and, more importantly, to higher subsidence in the SE Iberian Basin where the Eslida Fm was deposited; the area of interfingering is located along the $\mathrm{NE}$ margin of the Basin, from the Sierra de
Caldereros to the Teruel Area (Fig. 1), but the lack of outcrops in this crucial area hinders a more detailed correlation.

The origin and development of the Iberian Basin during the Permian-Triassic period is part of the general process of Pangea break-up and progress towards the $\mathrm{W}$ of the Neotethys Sea (Ziegler, 1988; Sopeña et al., 1988); extension took place along NW-SE-trending normal fault systems offset by NE-SW-trending transfer faults. The extensional history of the basin is complex and several pulses can be clearly distinguished. The Early Permian semi-graben geometry was replaced by a full-graben during the Late Permian and Early Triassic, but was regained during sedimentation of the Eslida Fm. A prominent, secondary high transverse to the main basin, the Cueva de Hierro-Tremedal High (Fig. 3, central area), conditioned alluvial sedimentation during this period and subdivided the Iberian Basin into two realms or sub-basins with different but comparable evolution and sedimentation; one to the NW and a second one to the SE. The Eslida Fm was deposited in the latter and the time equivalent Arandilla Fm in the former.

There were several source areas for the Eslida Fm; the main one is a distal source area in the Paleozoic Iberian Massif which is hundreds of kilometers to the NW. Secondary source areas were located in the hanging-wall block to the $\mathrm{W}$ of the Castellón-Teruel area and, probably, in the partially eroded underlying Cañizar Fm.

The aim of this paper is to describe the vertical evolution of the fluvial styles of the Eslida Fm, lateral correlation with coeval alluvial sediments to the NW of the Iberian Basin and unravel tectonic control on the styles exerted by the type of rift subsidence caused by the evolution of the basin boundary fault.

\section{Sediments}

A regional sedimentologic framework for the Eslida Fm in the eastern Iberian Ranges was established using 26 outcrop sections representing the sediments of eight different areas and one offshore well log over an area of about 

EL PARAISO
RAMBLA SOLANA
BEJIS
GATOVA
MONTAN
ESLIDA
VAL DE UXO
DESIERTO DE LAS PALMAS

(1)

(2)

(3)

(4)

(5)

(6)

(7)

(8)

(9)
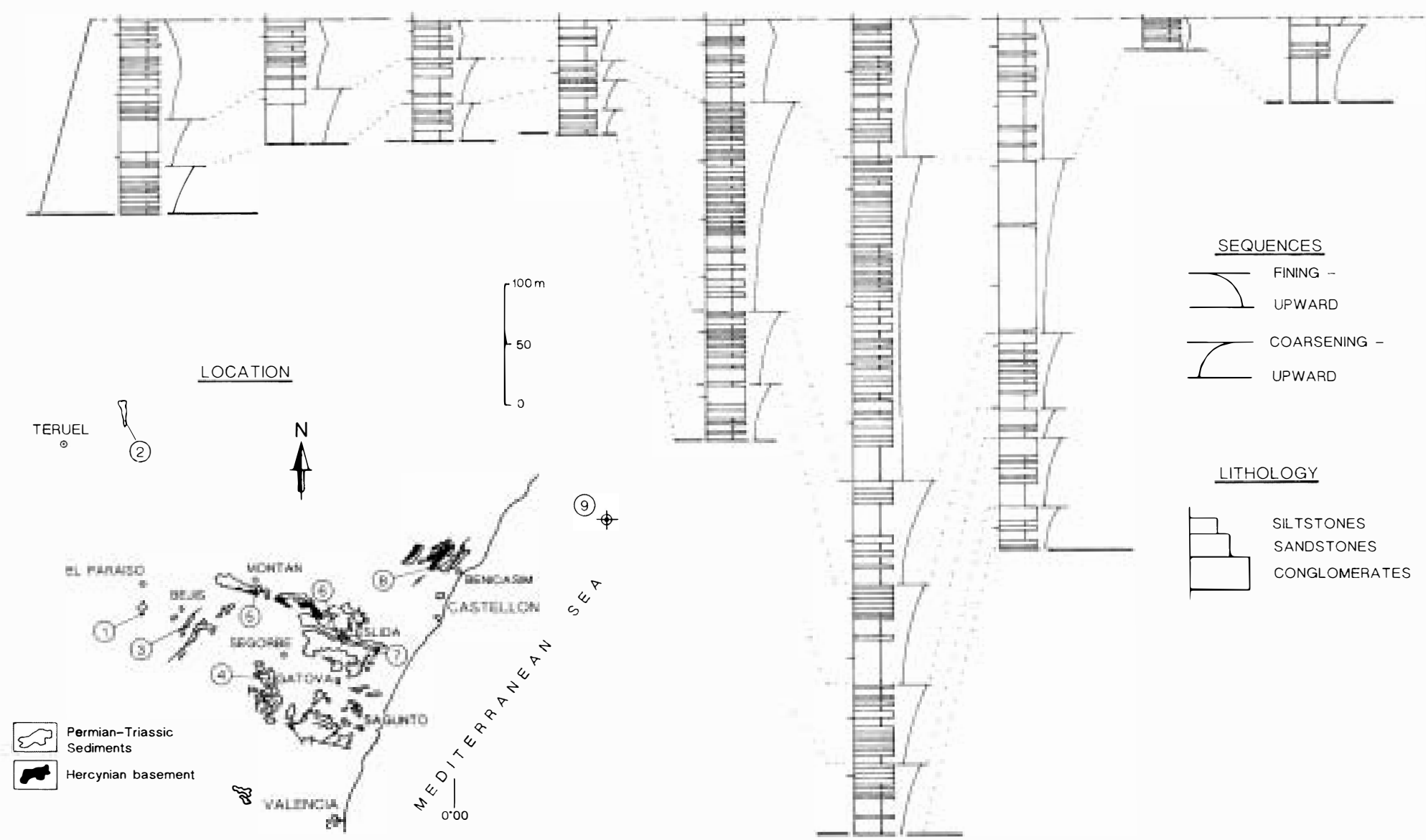

LITHOLOGY



SILTSTONES

SANDSTONES

CONGLOMERATES

Fig. 2. Logs of the field sections of the Eslida Fm. For the sedimentological detail see also Figs. 5 and 6. 


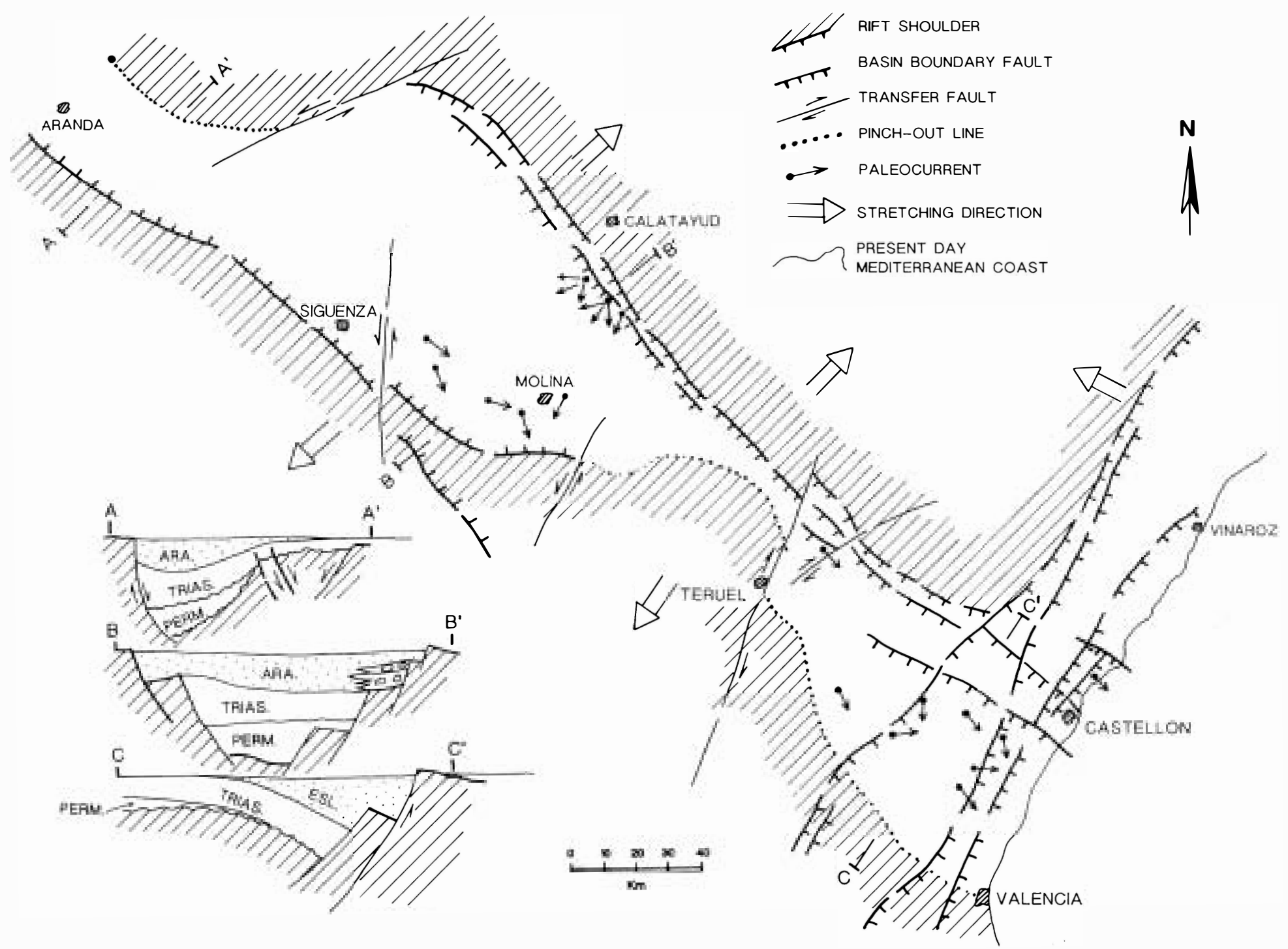

Fig. 3. Reconstruction of the Iberian Basin during the sedimentation of the Eslida Fm and the coe

Arandilla Fm, based on data of Ramos (1979), García-Royo and Arche (1987), Pérez-Arlucea (1987) and Muñoz et al. (1995) and original data of the authors. ote the opposite inclinations of the half-graben sections of the basin and the paleocurrents distribution. ARA and ESL mean Arandilla and Eslida Formations, respectively. For more detail of the geographical location see also Fig. 1. 
$10,000 \mathrm{~km}^{2}$ (Fig. 2). Different sequences were distinguished and were easily correlated due to the close spacing of the stratigraphic sections. Characteristic facies and facies associations were also defined and permitted the determination of the sedimentary environment and fluvial style.

\subsection{Petrological composition}

The Eslida Fm is mainly composed of red or pink sandstones and red siltstones, generally in a $40-60 \%$ proportion. Some isolated thin carbonatic and microconglomerate levels may also be identified.

Sandstones are fine- to coarse-grained $(0.130$ $0.4 \mathrm{~mm}$ ) and are composed of poorly sorted to well-sorted subrounded to subangular-angular grains. Point-counting results (Fig. 4) show that the detrital components are dominated by quartz. Quartz crystals are mainly mono- but also polycrystalline and represent $55-97 \%$ of the samples, although this percentage varies substantially from one study area to the next. Locally, sheared quartz grains also appear and abrasion in quartz grains is common in some areas. Monocrystalline quartz grains are inclusion-poor and commonly show corrosion.

Feldspar grains (mostly alkaline varieties) never exceed $45 \%$ and are differently altered, including total disintegration. The chemical weathering of feldspars is very clear in the Chovar-Eslida area where they were subjected to dissolution during the diagenesis that led to complete replacement by clay minerals (albitization process) (Fig. 4).

Clay minerals appear in two major mineral assemblages: illite-kaolinite-pyrophyllite and illite-chlorite-vermiculite-mixed layer clays in continental facies and those of marine influence, respectively. The pyrophyllite is also located in the Chovar-Eslida area indicating active phases of basin boundary faults (Alonso-Azcárate et al., 1997). The intergrowth of some clay minerals and

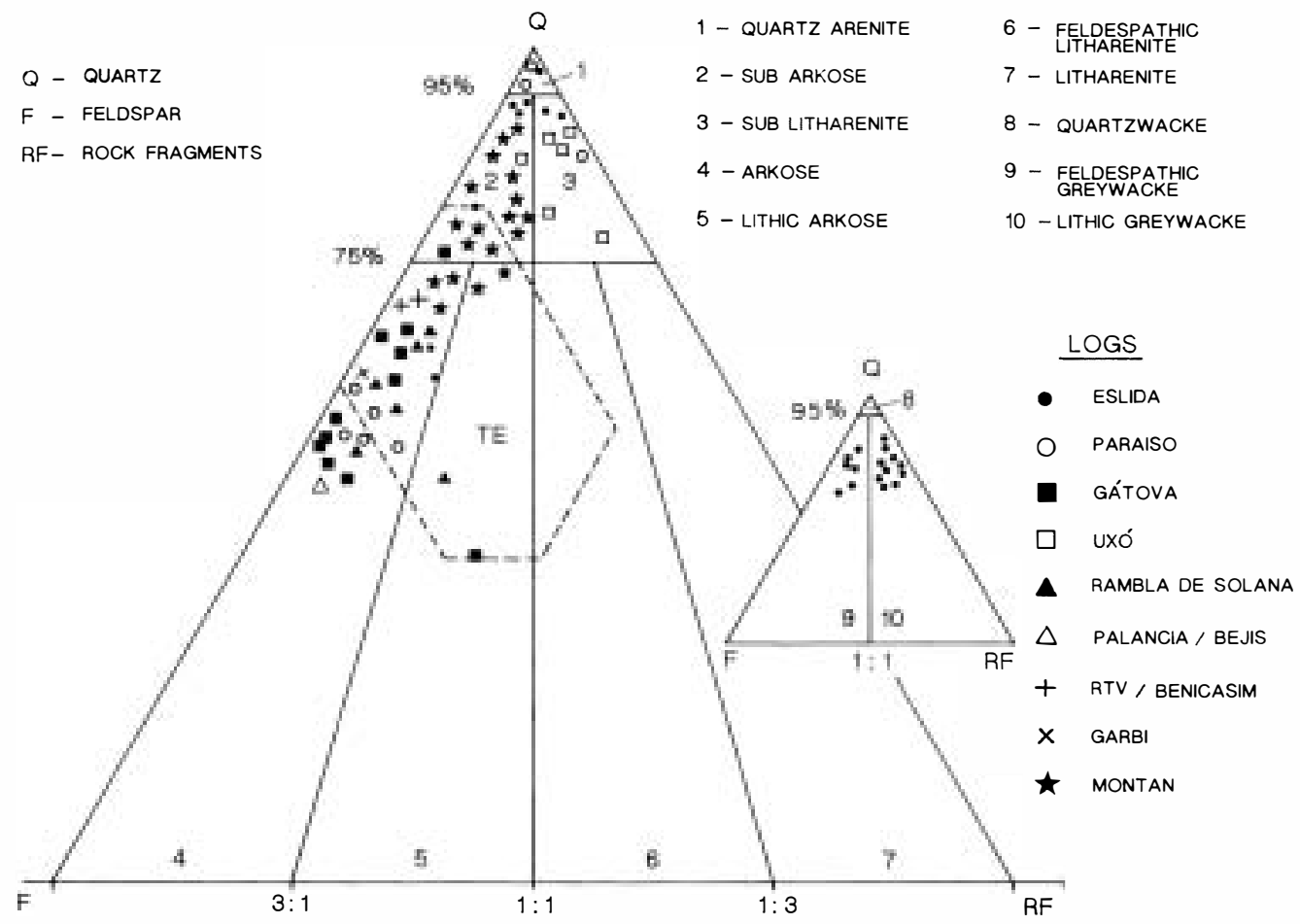

Fig. triangle shows the composition of the greywacke from the type section (Eslida Pass, close to the Eslida village). 
silt-sized grains of quartz and feldspar constitutes the matrix that never exceeds $8 \%$, except in the Chovar-Eslida area where the matrix constitutes more than $10 \%$.

Rock fragments tend to be the coarsest particles in the sandstones. They always constitute less than 9\% and mainly indicate an igneous origin. Some thin levels with xenotopic-idiotopic dolomicrospar crystals with high Fe content appear; they are in clear lateral relationship with vertical nodular soil development.

Particles of sandstones show a very similar composition in each sample. A slight general change in the percentage of feldspar increasing towards the SE, and the disappearance of pyrophyllite in the upper half of the formation in the Chovar-Eslida area, may be observed. In a triangular classification with quartz-feldspar-rock fragments as the principal components for sediments with less than 15\% fine-grained matrix (Folk, 1974) (Fig. 4), arkose is clearly dominant and the remainder is divided into sub-arkose, sub-litharenite and quartz arenite. Rocks with more than $15 \%$ matrix (represented in the smaller triangle in Fig. 4) are quartzwacke and feldespathic greywacke. This composition and some of the above mentioned characteristics point to a granitic and gneissic general origin, although appreciable differences in composition between the study areas also indicate some different point source areas more or less separated by the active faults. The general composition also fits well with the so-called 'passive margin' by Yerino and Maynard (1984) (TE in Fig. 4) and the 'transitional continentalbasement uplift' provenance terrain of Dickinson (1985).

\subsection{Facies and representative sequences}

The field description of the sediments and their sedimentological interpretation is based on facies differentiation. Ten facies were identified as the most common. Their lateral association and vertical succession in the field allow us to separate six sedimentary sequences. These sequences represent different fluvial styles (Allen, 1970; Cant and Walker, 1978; Morison and Hein, 1987) and their analysis and vertical distribution indicate the fluvial vertical evolution of the Eslida Fm.

The field aspect, general description, code and interpretation of the differentiated facies are synthesized in Fig. 5. The interpretation is based on very well known standard works such as those written by Smith (1971), Walker and Cant (1979), Leeder (1973), Collinson (1986) and Miall (1996) among others.

The different facies associations and their vertical sequences are considered to be the most representative, although not the only possible ones. Their vertical distribution in a standard $\log$ is shown in Fig. 6. This standard log is based on section number 6 of Fig. 2 since it is the thickest and best preserved of the study area. Some of the sequences can be observed in most of the section, while others are of reduced vertical distribution indicating a permanent change in the sedimentological style.

Sequence interpretation is based on previous works as indicated in Fig. 6. All belong to fluvial depositional systems that can be subdivided into within-channel deposits, floodplain elements and features deposited at the margin of the channel and floodplain (Allen, 1965; Lewin, 1978; Brierley, 1996).

Channel deposits can be isolated lenticular bodies in the floodplain or amalgamated sheets (Fig. 7). This arrangement of the channels and the differentiated sequences that constitute the channel-fill and the floodplain deposits allows us to reconstruct the vertical evolution of the fluvial style. Thereby, the geomorphic units or elements shown in Fig. 6 determine, among others, the three components of river depositional systems cited above (Brierley, 1996). Thus, Pcs-1, Tcs, Ecb and Es would constitute within-channel elements, Pcs-2 and $\mathrm{Pl}$ would represent channel-marginal elements, while $\mathrm{Mb}$ and Ms-s would represent floodplain elements.

The vertical arrangement of these elements indicates representative depositional sequences of fluvial channels, and their characteristics adequately correspond to braided, meandering and anastomosed river styles (Richards, 1986). Fig. 7 shows the vertical distribution of these fluvial styles in the Eslida Fm, as well as the transition to marine influence represented by $\mathrm{Ab}$ and Lsm elements. 
Medium angle planar cross-beds

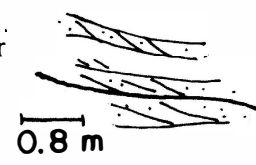

Red. fine to medium sand stones. Sets up to $1.2 \mathrm{~m}$.

Plant remains are frequent in the foresets.
Pcs-1 Transverse-linguoid bedforms.
Trough cross-beds

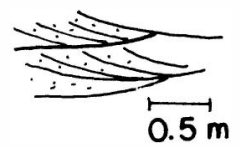

Red. fine to medium sand stones.

White to pink fine to medium sandstones. Sets up to $1.6 \mathrm{~m}$.
Tcs Sinuous-crested

linguoids dunes.

Ecb Point bars

Epsilon cross-bedding $2.6 \mathrm{~m}$ $=$

Erosional scour surfaces

Low angle $\left(<10^{\circ}\right)$ Cross-bedding
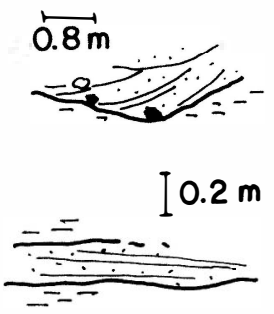

Parallel lamination

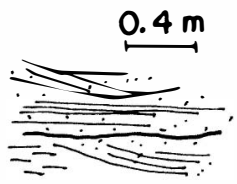

Massive or with horizons with iron oxides nodules with sporadic carbonatic laminations.

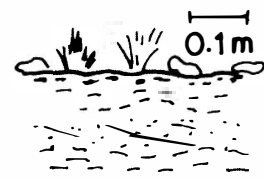

$0.25 \mathrm{~m}$

Alternating siltstones marls and sandstone massive levels.

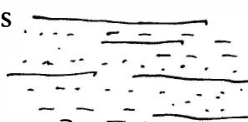

Red. thin bioturbated levels alternating with yellow-ochre marls and siltstones flat levels

Ab Distal alluvial with marine influence

Ochre. yellow and pink medium sandstones with very thin yellow anhedral cristal dolomite levels at the top with high iron content

$\mathrm{Mb}$

Soil development. Segregation of iron oxides due to wetting and drying over many redox cycles stream-laid sand stones in high energy shallow sheetfloods

Lenticular and flaser bedding

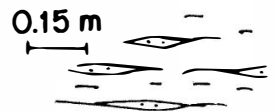

Red siltstones and intercalated small lensoidal fine sand bodies

Lsm

Tidal (seasonal) deposits.

Massive siltstones and sandstones
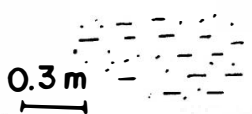

Dark red siltstones with some fine intercalated sandstone levels

Ms-s

Floodplain deposits.

Fig. 


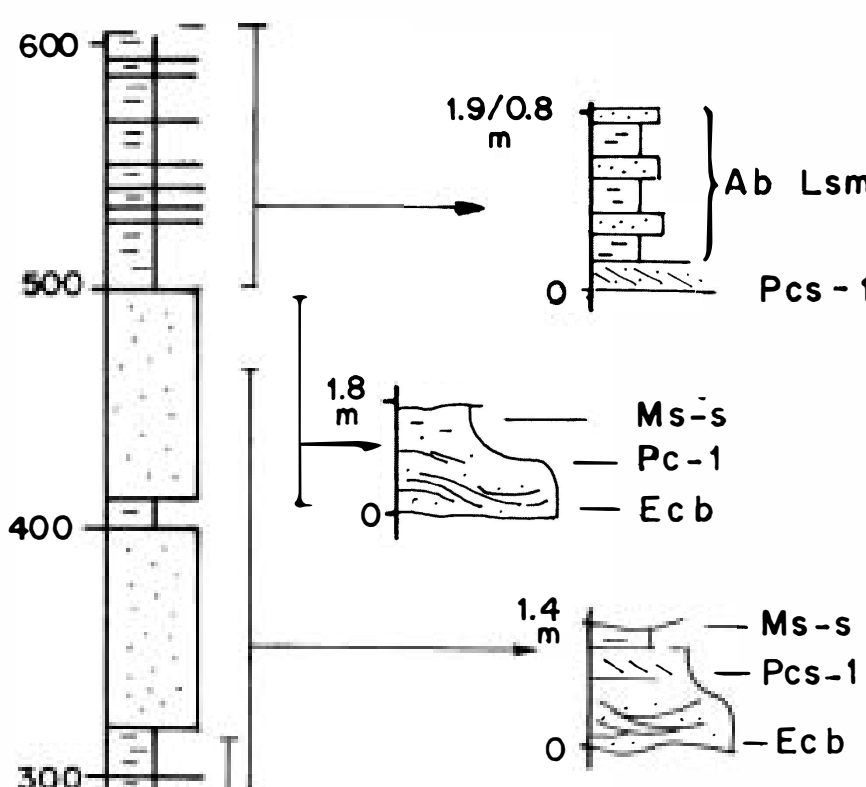

Distal alluvial sediments in a wide and flat surface, in shallow water channels and sporadic marine influence

Nombela et al., (1995):

Dalrymple \& Makino (1989).

\section{ \\ Sandy fluvial meandering deposits.}

Puigdefábregas (1973):

Jackson (1981)

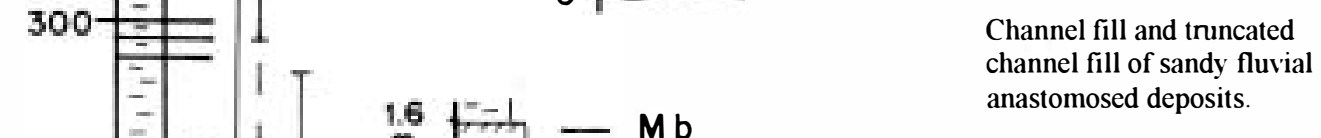

Sandy fluvial braided deposits

Rust (1981); Allen (1965)

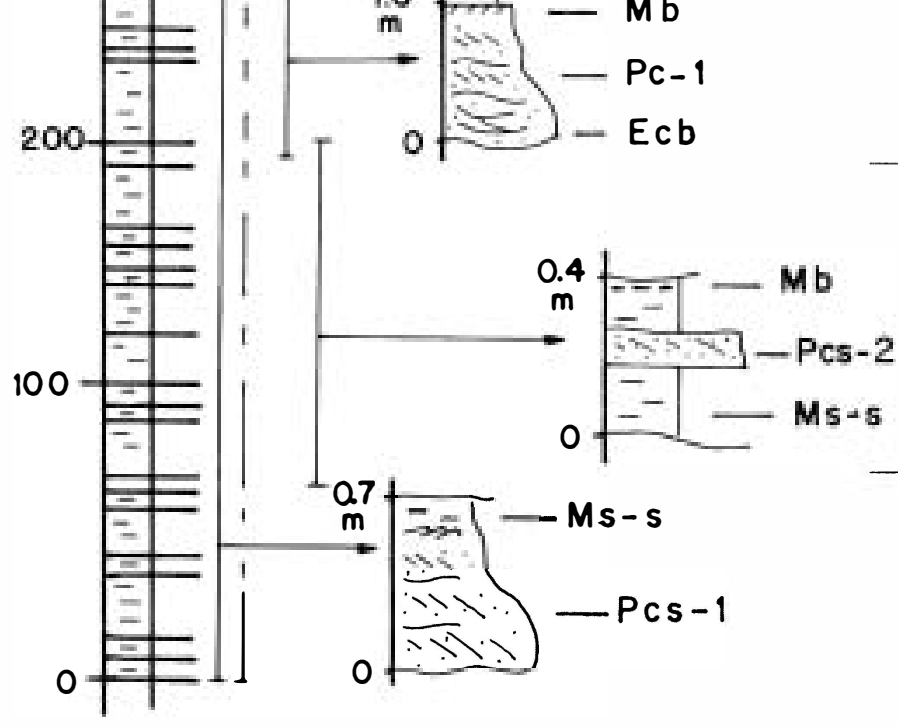

Smith \& Smith (1980):

Kirschbaum \& Mc Cabe (1992).

Complex sheet-sandstone bodies of crevasse splays with sporadic channels intercalated in floodplain deposits

Bown \& Kraus (1987):

Smith et al., (1989)

Lower flow regime channel fill. Linguoid, transverse bar or sand waves.

Haszeldine (1983): Kirk (1983).

Fig. 6. Standard log based on field section 6 (of Fig. 2) with facies associations and their sedimentologic interpretation (Allen, 1965; Puigdefábregas, 1973; Smith and Smith, 1980; Jackson, 1981; Rust, 1981; Haszeldine, 1983; Kirk, 1983; Bown and Kraus, 1987; Dalrymple and Makino, 1989; Smith et al., 1989; Kirschbaum and McCabe, 1992; Nombela et al., 1995). See also Fig. 5 for the interpretation of the lettercode. 


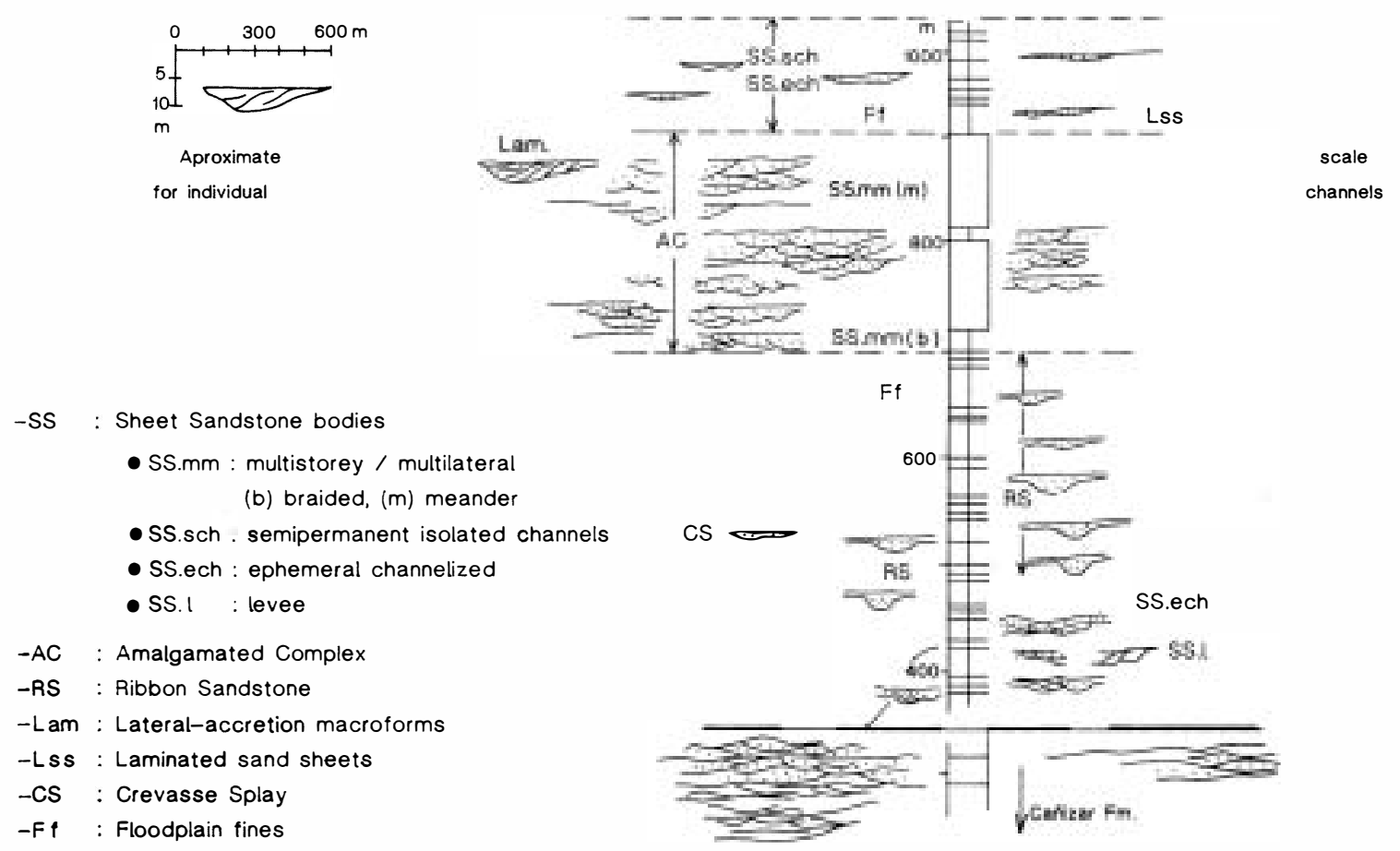

Fig. 7. Sedimentological interpretation of the channellised and non-channellised alluvial facies of the Eslida Fm and their vertical evolution. The standard log is based on field section 6 (Fig. 2) but the general sandstone bodies style can be clearly followed laterally all along the study area.

This vertical and lateral distribution of the different fluvial styles mentioned shows a clear relationship with the tectonic control and is fundamental for determining the rate of subsidence, main and secondary fault activity, and morphology (symmetry or asymmetry) of the developing basin, as will be discussed later.

\subsection{Paleocurrents}

Paleocurrent analysis is used in this section for the reconstruction of local and regional paleoflow, vertical changes in flow direction through the stratigraphic sections and vertical changes in orientation of the system in response to paleogeographic changes in the study basin.

The paleocurrents measured are always unidirectional approximately indicating NW to SE (Figs. 3 and 8 ). The spread is always smaller than $105^{\circ}$ and rarely exceeds $35^{\circ}$ in each section. Readings are taken from trough cross bedding
(68\%), channel and scour (23\%), parting lineation (7\%) and others (2\%). The uncertainty of these measures is derived from dip compensation, but is always small (less than 5\%).

Most of the paleocurrents trend towards the E. However, the Montan-Eslida area (Figs. 3 and 8) presents a clear general S-SE paleoflow trend. On the other hand, the upper half of the logs and the more sandy levels are those presenting greater dispersion.

A general interpretation could indicate that the current trend was very constant, but that at the start of sedimentation, areas close to important faults such as Montán and Eslida (Fig. 3), had some local paleocurrent variation and pointed towards the $\mathrm{S}$. These areas also coincide with the maximum rate of sediment accumulation (Fig. 9A) and with the area where the pyrophyllite appears, as well as the sediments affected by diagenesis and modification of some petrological components as indicated above. 


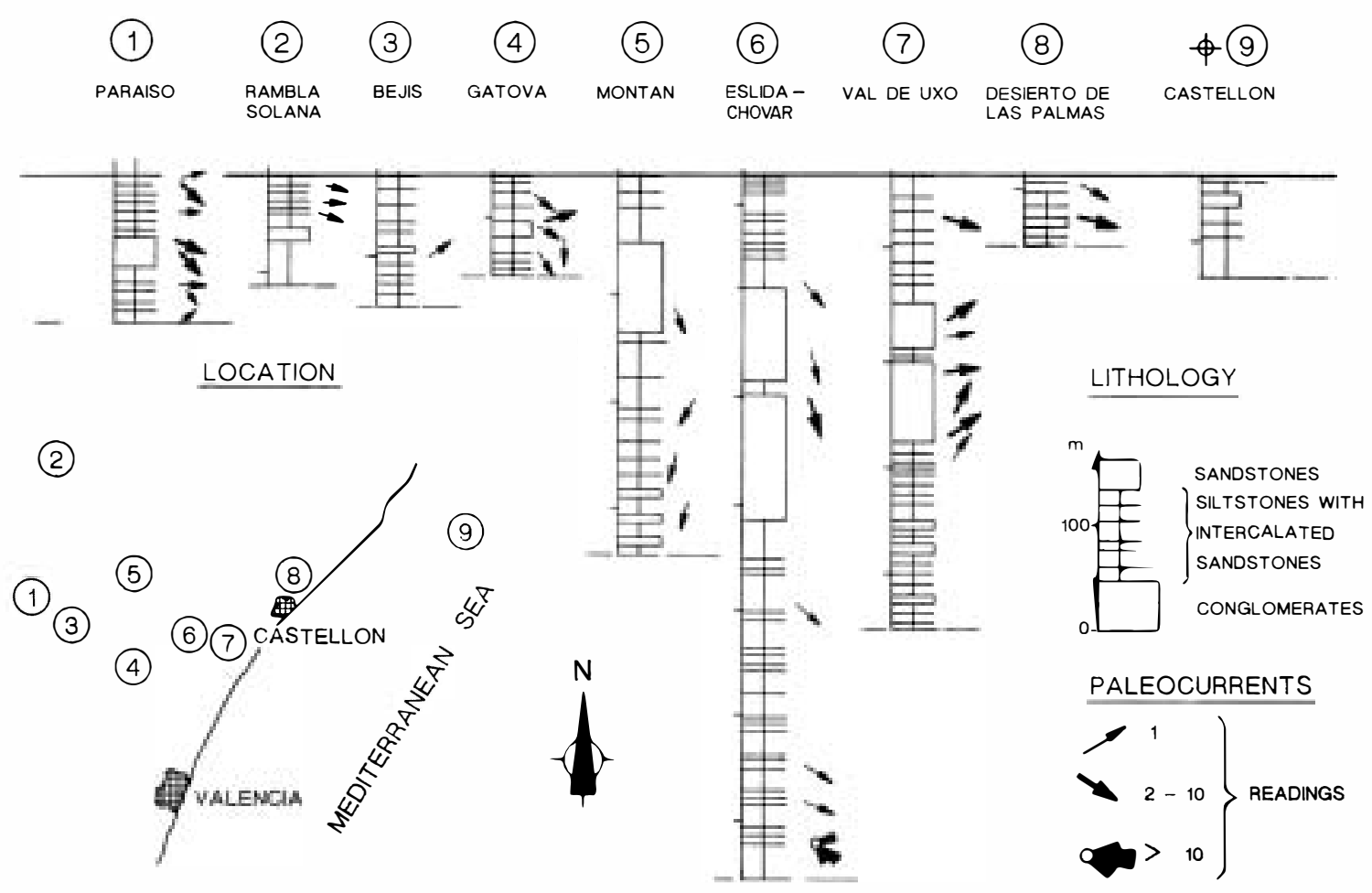

Fig. 8. Lateral and vertical distribution of the studied paleocurrents of the Eslida Fm. Note the change in orientation in the Montán and Chovar-Eslida sections. See also Figs. 2 and 3 for more detail about the geological and geographical distribution of the logs.

The sandy portions of the upper part of the logs with large paleocurrent dispersion coincide with the sediments related to meandering sedimentation and sporadic marine connections near the top of the sections previously described (Fig. 7), indicating a general tendency towards regional stability.

\section{Tectonic, geomorphic and climatic controls on the alluvial sediments of the Eslida Fm}

Sediment discharge into a basin and the geometry of the basin itself are the first-order controls on fluvial style and three-dimensional architecture; the magnitude of discharge, the nature of the sediments delivered to the basin and the relative importance of longitudinal vs. transverse transfer systems are of fundamental importance in the study of alluvial successions (Heller and Paola,
1992, 1996; Summerfield and Hulton, 1994; Kooi and Beaumont, 1996; Leeder, 1997).

These factors depend on three basic mechanisms:

Tectonic activity. A rift basin like the Iberian Basin is created by extension which is limited by normal basin boundary faults whose activity creates subsidence. Subsequently, the basin geometry and the periods of rapid or slow subsidence create accommodation space at very different rates.

Geomorphic factors. The catchment area, where the nature of the bedrock, rate of uplift, weathering and erosion control of the nature and supply of sediment is of fundamental importance in interpreting alluvial successions.

The rate of sediment transfer to the basin also depends on the type of fluvial network, its competence and capacity, and the longitudinal (fluvial) to transverse (alluvial fan and antecedent river systems) rate of channels present in the basin. 


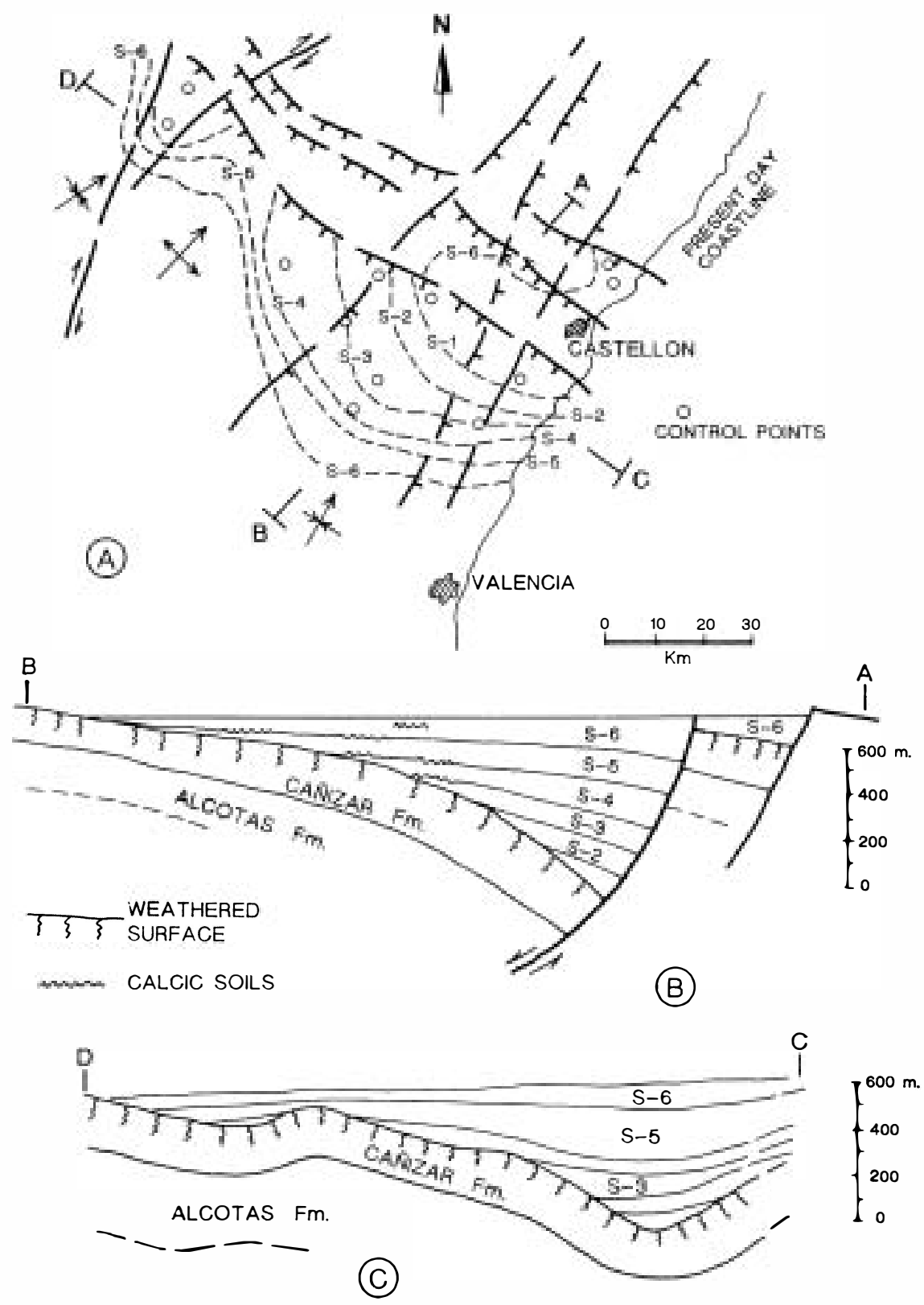

Fig. 9. (A) Areal extent of each of the differentiated sequences of the Eslida Fm. Open circles represent control points. (B) Transverse sketch of the onlap relationship of the Eslida Fm with the basement. Note the distribution of the calcic soils in the distal part of the basin and the weathered surface on top of the Cañizar Fm. (C) Longitudinal sketch of the Eslida Fm relationship with the basement. Note the two depocenters in the Teruel and Eslida areas.

Climatic factors. The type of climate controls weathering processes, the discharge of the fluvial network, pedogenic processes in the basin, and the type of vegetation.
As previously stated, the Eslida Fm has a small deposition area in comparison with the previous alluvial deposits of the Iberian Basin, but is by far the thickest and presents such a strikingly different 
fluvial style to the coeval Arandilla Fm (Ramos, 1979) that we consider its lateral equivalent to the NW. The rate of deposition is high, averaging $0.264 \mathrm{~m}$ per thousand years. Here we will review the tectonic, geomorphic and climatic factors responsible for these characteristics.

\subsection{Tectonic controls}

The field studies of the Eslida Fm and the timeequivalent Arandilla Fm show that the configuration of the Iberian Basin during the lower Anisian (Middle Triassic) was a series of half-grabens and full-grabens interconnected by transfer faults (Fig. 3) (Ramos, 1979; García-Royo and Arche, 1987; Pérez-Arlucea, 1987; López-Gómez and Arche, 1993a; Muñoz et al., 1995).

Three parts can easily be distinguished: the SE part, where the Eslida Fm was deposited; a halfgraben bounded to the NE by a NW-SE normal lystric fault; and a well-developed roll-over in the hanging-wall where synchronous sedimentation and deformation is recorded as a series of sediment wedges pinching out against the basement (Fig. 9A and B). The fault plane dips to the SW and interferes from the Eslida area to the $\mathrm{E}$ with another important normal fault system of NESW orientation dipping to the SE (Fig. 3). To the NW, the basin boundary fault is offset by a prominent transfer fault in the region of Teruel (Fig. 3). Two depocenters, one in the Teruel area and a second one in the Eslida area, are present (Figs. 2 and 9C).

A major re-entrant of the basement, probably due to a smaller rate of extension to the NW, separates the SE domain of the Basin from its central part, interconnected only by a narrow corridor in the Ojos Negros area (Fig. 1) (PérezArlucea, 1987; this paper). This sub-basin is bounded by antithetic normal faults and shows a full-graben configuration. To the NW, an important transfer fault and a new basement re-entrant mark the limit with the NW Iberian sub-basin, as described by Muñoz et al. (1995), bounded by a normal lystric fault in the SW margin and a welldeveloped roll-over in the hanging-wall to the NE, where, again, the fluvial sediments pinch out laterally against the basement (Fig. 9A and B).
The alternation of the direction of half-graben asymmetry is obvious, and the full-graben form is a transition interval of the alternating half-grabens; the lystric nature of the basin boundary faults in a half-graben section is clearly shown by the asymmetric distribution of isopach lines which reveal the depocenters to be close to the basin boundary faults (Fig. 3, sections $\mathrm{A}-\mathrm{A}^{\prime}$ and $\mathrm{C}-\mathrm{C}^{\prime}$ ).

The juvenile rifts usually show a prevalence of half-graben geometries as in the classic Tanganyka and Malawi Rifts described by Rosendahl et al. (1986). The Eslida Fm was deposited during the third and last syn-rift extensional period. The $\boldsymbol{\beta}$ factor, calculated from the subsidence curves, is 1.17 for the Cañete, 1.22 for the Teruel and 1.29 for the Chovar-Eslida areas (Fig. 10), illustrating the increase in extension to the SE in the Iberian Basin.

In more detail, extension during the sedimentation of the Eslida Fm was not continuous but probably took place in pulses. Rapid extension during the beginning of a pulse led to rapid creation of accommodation, and most or all the sediments delivered to the basin were preserved. As the rate of creation of accommodation diminished with time, the sediments were partially reworked, the basin became oversupplied and the isolated, ribbon geometry of the channellised sandstone bodies at the base of each cycle evolved to amalgamated sandstone bodies. The coarseningthickening sequences 1 to 5 (Fig. 2) represent the period of dominant vertical subsidence or the synrift period, and the fining-thinning sequence 6 , the cessation of active extension, and a period of lateral shifting and abandonment of the fluvial systems accompanied by the beginning of a major transgression.

The onlapping geometry of the alluvial sequences and the presence of two depocenters reveal that extension during Eslida Fm sedimentation started in the Eslida area, where the oldest sequences were deposited (Fig. 9) and propagated to the NW in time, as well as the increase in the area of the active depositional basin.

The mean rate of accumulation during this extensional period is estimated as $0.2-0.28 \mathrm{~m}$ per thousand years. 

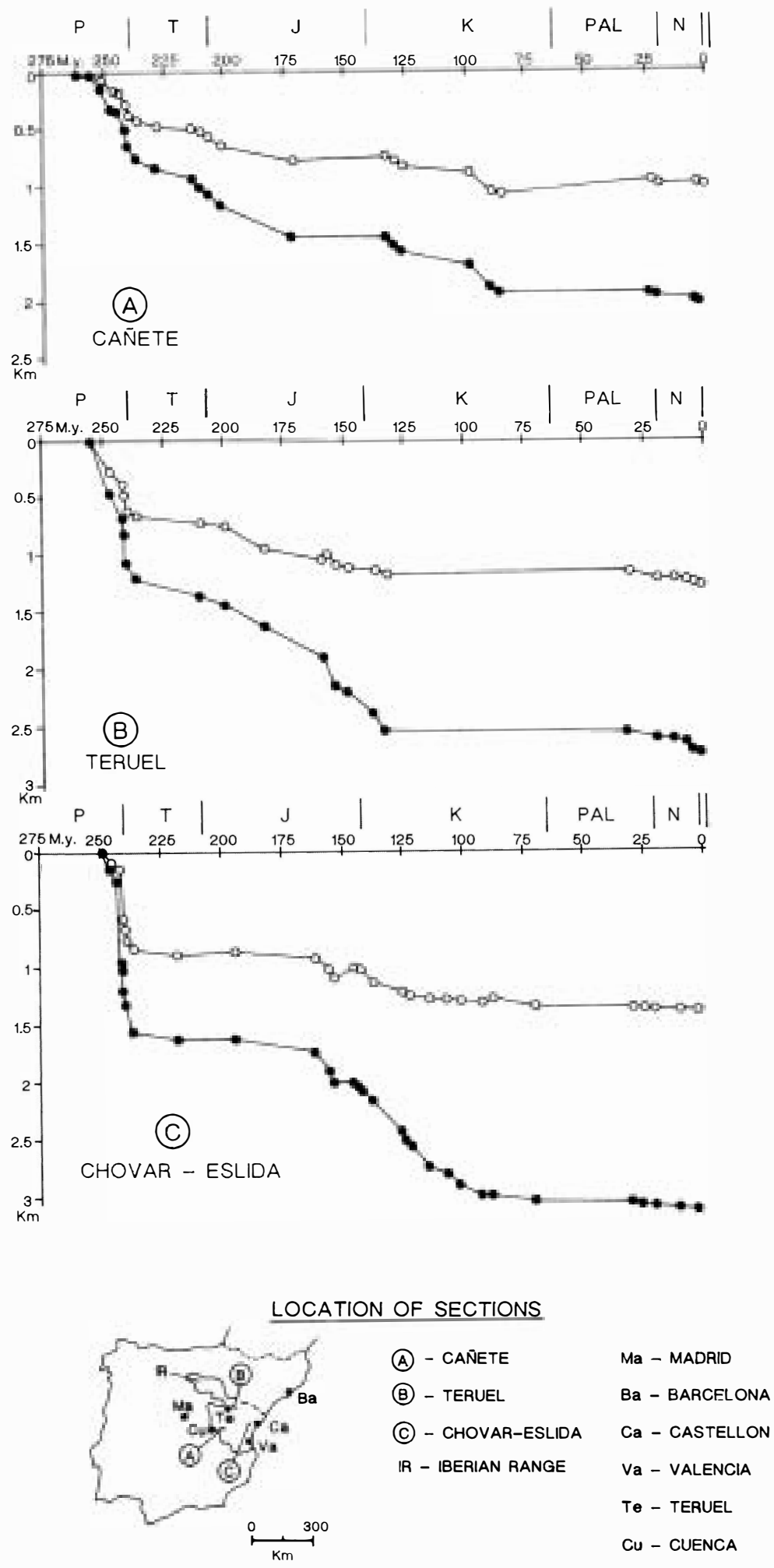


\subsection{Geomorphic controls}

The main geomorphic controls on the deposition of the Eslida Fm are: the basement rocks in the catchment area and their weathering processes; the local and regional slope; the type of fluvial network and the relative importance of channel and overbank (floodplain) deposits.

Three areas were identified to supply sediments to the Eslida Fm depositional basin: one, of minor to negligible importance, in the NE rift shoulder (Fig. 3) which is composed of Ordovician to Early Carboniferous low-grade metamorphic slates and quartzites; a second one in the SW hanging-wall composed of paleozoic slates and quartzites and granite and/or gneiss bodies; and a third, and much more distal one, situated hundreds of kilometers to the NW along the margin of the Iberian Basin which consists of Paleozoic and Precambrian igneous rocks of granitic nature and gneissic complexes of comparable composition. The latter was the main source area.

Weathering processes in the catchment area are not well established, but chemical processes were not sufficiently aggressive to obliterate the feldspar and rock fragments found in the Eslida Fm at proportions of up to $30 \%$ (Fig. 4).

A further unidentified source area is the top of the underlying Cañizar Fm, exposed along the SW margin of the basin that presents an eroded top, reduced thickness along the prominent re-entrant of the Cueva de Hierro-Albarracín and bleaching, rootlet horizons and $\mathrm{Fe}$ duricrusts at the top.

The regional and local slope are among the fundamental variables that control discharge and fluvial channel geomorphology. Slope is controlled by subsidence and depositional processes; it is to be expected that rapid changes of slope occur in tectonically active areas such as rift basins during the syn-rift period (Alexander and Leeder, 1987; Heller and Paola, 1996). Changes are more frequent during the most active periods, i.e. at the beginning of each tectonic pulse, and the avulsion rate will increase locally. Field data (Figs. 7 and
11) corroborate that ribbon sandstones, floodplain fines and crevasse splay deposits are dominant architectural elements of the lower part of each of the alluvial sequences due to increased accommodation space to be filled and the inherent instability of the channels.

At the end of each tectonic pulse, increased stability and reduced creation of accommodation space led to a more stable channel configuration, reduced avulsion rate and the formation of amalgamated complexes of sheet geometry (Figs. 7 and 11) and the washing out of the floodplain fines. These configurations are in good agreement with the predictions of the stacking arrangements of fluvial sand bodies based on the models of Leeder (1978) and Bridge and Leeder (1979).

The lateral profiles of the basin show the depocenters near the basin boundary fault, where the braided configuration is dominant (Fig. 11B). Away from the most active part of the alluvial basin, only avulsion processes of high magnitude cause the incision and establishment of alluvial channels (Fig. 11A) and the area is dominated by floodplain processes, i.e. non-channellised sedimentation. Reduced accretion rate and accommodation rate lead to subaerial exposure during long periods and the formation of calcic soils absent in the most active parts of the alluvial basin (Fig. 9B). The dominant configuration of these secondary fluvial channels is meandering.

The onlap relationship of successive sequences with the basement and the absence of lacustrine deposits in the Eslida Fm (Fig. 9) indicate that sedimentation rate was equal to or higher than the rate of creation of accommodation, and that the basin was overfed during this period. As the Iberian Basin consisted of at least three axiallyconnected basins during that period (Fig. 3), the Sigüenza-Molina sub-basin (where the time equivalent Arandilla Fm was deposited) can be considered as a low withdrawal basin, with extensive reworking of fluvial sediments and high channel body interconnectedness. In contrast, the TeruelEslida basin may be interpreted as a high-with-

Fig. 10. Total and tectonic subsidene curves for three contrasting areas of the Iberian Basin. The polifasic nature of the extension during the Permian and Triassic is clearly shown. See also Fig. 1 for more detail in the geographical location of the sections. 


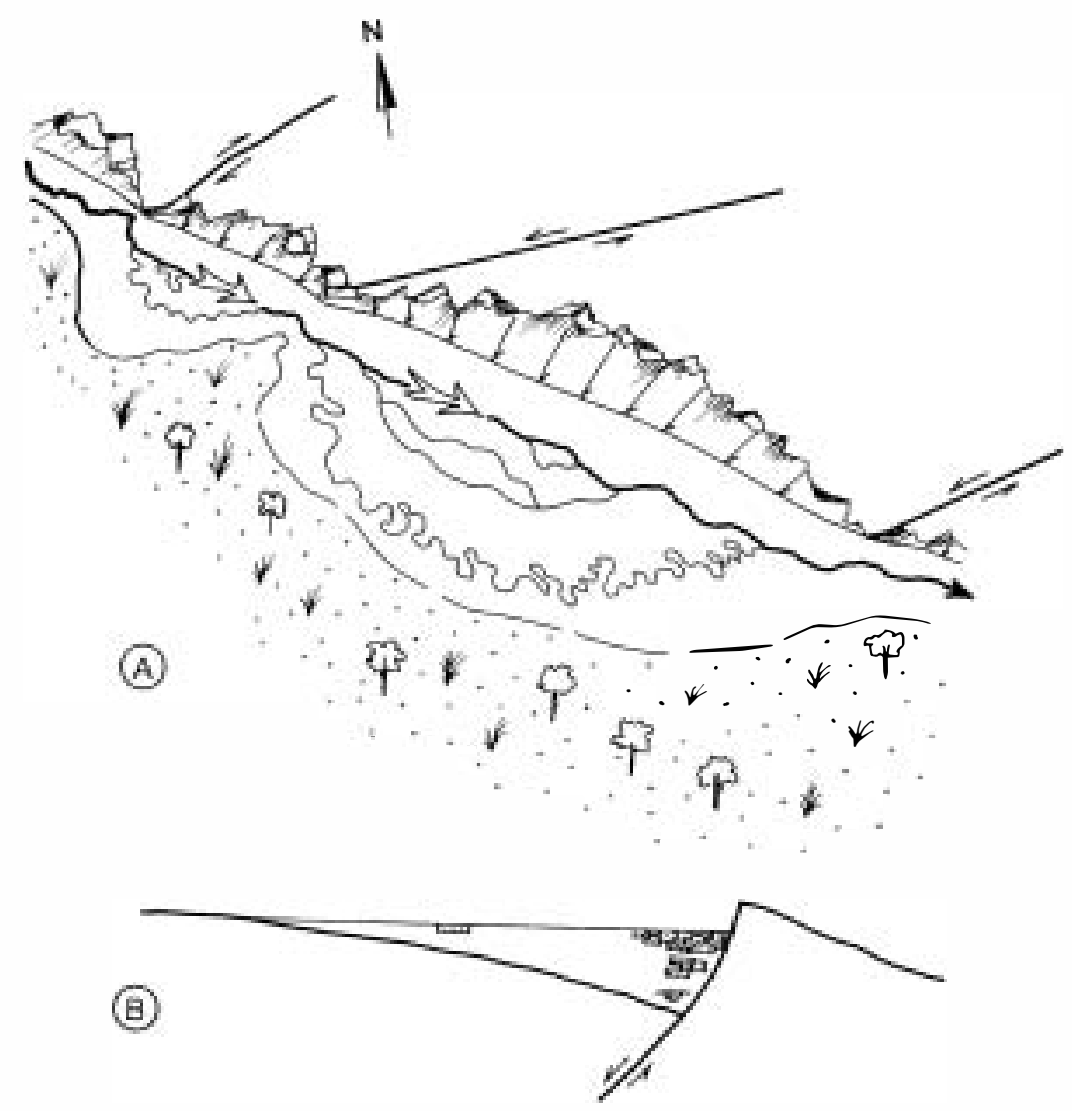

Fig. 11. Panoramic reconstruction (A) of the SE Iberian Basin during the deposition of the Eslida Fm. The exposed basement in the hanging-wall block is shown, as well as the lateral distribution (B) of the channellised sandstone bodies.

drawal basin with preservation of floodplain deposits, increased thickness of the fluvial sequences and lower channel body interconnectedness for the Eslida Fm (Leeder, 1997).

The Iberian Basin shows a predominance of axial or longitudinal drainage with respect to lateral or transverse drainage which is uncommon in most rift basins; alluvial fan deposits derived from the scarps of the basin boundary faults have only been located in the middle part of the SigüenzaMolina sub-basin, one of the three laterally linked basins (Fig. 3). Even the presence of complex, mid-basin transfer faults and basement highs causing polarity changes between sub-basins does not change the drainage pattern. The dominance of the axial clastic delivery system indicates that sedimentation rates exceeded subsidence rates and the basin filled up with sediments (overfed basin).
The development of large alluvial fans along the rift shoulders requires the presence of antecedent rivers cutting across them as they grow that drain extensive parts of the back-rift hinterland, or the development of an obsequent network by scarp retreat and the creation of small, high-slope drainage basins feeding each alluvial fan system (Allen and Hovius, 1998).

Field evidence (maps, sections, palimpastic reconstructions) shows that no major river system cut across the rift shoulders of the Iberian Basin during the deposition of the whole Buntsandstein Facies; the Iberian Basin was isolated by a paleozoic high from the coeval Ebro, Catalan and Prebetic basins (Arche and López-Gómez, 1996).

Scarp retreat along the basin boundary faults proceeds at rates ranging from 0.16 to $2.0 \mathrm{~mm} / \mathrm{yr}$, according to the data compiled by Gutierrez et al. 
(1998), Calvache et al. (1997) and Vergés et al. (1996) depending on the nature of the bedrock and climate. As the basement exposed along the rift shoulders consists of slates and quartzites, indurated but not heavily tectonised, the lower estimates apply to the Eslida Fm period of sedimentation is about $2-2.5 \mathrm{Ma}$. This gives a total maximum retreat of $2.5-3 \mathrm{~km}$, insufficient for the creation of large catchment areas and the development of fans. For example, in the classic Death Valley fan systems, the catchment length is 5$12 \mathrm{~km}$ (Allen and Hovius, 1998).

An alternative mechanism of supply of clastic sediments to the foothills of a tectonic relief is hillslope landslide, but this is efficient only with bedrock uplift rates of $2-12 \mathrm{~mm} / \mathrm{yr}$ and the presence of antecedent underloaded rivers that successfully remove the supplied detritus (Burbank et al., 1996).

Thus, we can conclude that conditions for the development of efficient transverse drainage networks and associated alluvial fans were developed only locally (Fig. 11) during the lower Anisian in the Iberian Basin due to the combination of low scarp retreat rate and the absence of antecedent rivers.

Limited resequent river networks across the hanging-wall were formed in the SE Iberian subbasin feeding the Eslida Fm, with a sand supply from the Cuenca region, where both Paleozoic low-metamorphic rocks and granites have been observed in basement boreholes.

Another important characteristic of the Eslida Fm exercising geomorphic control is the transverse lateral change from channel-dominated sections near the basin boundary fault (Eslida and Vall de Uxó sections, Fig. 2).

As active channels with abundant sediment supply tend to be superelevated above the floodplain (Heller and Paola, 1996) and, in the case of the Eslida Fm, they were constrained to the most subsiding area close to the basin boundary fault, a substantial area of the SE Iberian Basin was a floodplain with only minor active channels (Fig. 11). This is the result of infrequent whole river avulsions. Both crevasse splay deposits and diffuse overbank deposits can easily be recognized in sections situated 10 to $30 \mathrm{~km}$ from the basin boundary fault where they form 80-95\% of the sediments.

This indicates that this marginal area was an efficient trap for fine sediments, with an average

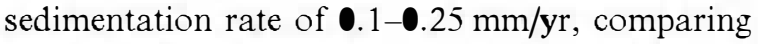
well with lower estimates for large present-day rivers such as the Amazon and Brahmaputra (Mertens, 1994; Allison et al., 1998; Dunne et al., 1998). Long periods of exposure in the floodplain area led to the development of calcic soils, not present in the more active channel area to the NE. This indicates that, despite being a superelevated area, avulsion and breaching by crevasses was an episodic process, allowing for long periods of exposure.

\subsection{Climate controls}

The role of tectonism can be clarified if climatic conditions and rates of basin subsidence can be independently determined. Different analyses provide evidence for the climatic setting and changes in ancient siliciclastic sediments, such as mineralogy, plant remains, pollen and spore assemblages, petrology, soil development and sedimentary structures. In this case we are not interested in determining the main attributes of the climate during sedimentation of the Eslida Fm, but identify important effects of that paleoclimate on the sediments. Few studies have described the climate of the Iberian Plate during the Lower-Middle Triassic (see Doubinger et al., 1990; López-Gómez and Arche, 1993b; Sopeña et al., 1995).

Palynological studies show an evolution towards warmer and dryer environmental conditions from Late Permian to Late Triassic in the Iberian Ranges (Doubinger et al., 1990). During the Early Triassic, there was enough precipitation for conifers and ferns to thrive on the banks of the streams (López-Gómez and Arche, 1993b). However, calcareous soils (nodulars, massive or laminated) occur in the Eslida Fm, indicating rainfall between 200 and $600 \mathrm{~mm} / \mathrm{yr}$, with evaporation that exceeds precipitation (Tucker, 1991). Locally, ferruginous nodules may envelope siltsize mineral grains and may be interpreted as segregation of iron oxides due to wetting and 
drying over numerous redox cycles (McCarthy and Plint, 1998).

Thus, dry and rainy seasons could alternate during sedimentation of the Eslida Fm. This is consistent with the tropical to semi-tropical setting of Iberia (Ziegler et al., 1981) and also with the wind circulation proposed by Kutzbach et al. (1990) for the Permian-Triassic period including westward flow at the equator, boundary currents along the northern and southern margins of the Tethys, and eastward flow at higher latitudes. Since the study area was very close to the Tethys margin during sedimentation of the Eslida Fm (LópezGómez and Arche, 1993a), high orographic rainfalls would occur on upwind slopes and rain shadows downwind of high topography.

A complication involved in determining the climate in long fluvial sedimentary sequences is that the climate of the sediment source area and that of the depositional basin may not be the same. This occurs in many present-day examples (Euphrates and Tigris, Po or Rhone rivers) and quite possibly occurs in the case of the Eslida Fm, where the main source area was located hundreds of kilometers to the NW.

Although the amount and distribution of rainfall in time are two important factors that control sedimentation, we consider that for sedimentation of the Eslida Fm, tectonism was mainly responsible for the fluvial styles and body assemblages and locations described above. The different styles of subsidence allowed the appearance of vertical piled sand bodies, amalgamated or isolated bodies and the dominant upward fining of fluvial successions. These are also the result of tectonic pulses (Heward, 1978), particularly when interbedding of coarse and fine sediments is absent, and coarse sediments could not indicate periods of increased rainfall (Frostick and Reid, 1989). However, the dominant seasonal character could increase the sediment yield of the Eslida Fm, since the vegetation cover is limited by the constraints of the dry season, so that runoff is more flashy and therefore more competent in the wet season (Walling and Webb, 1983). The piles of trunks and leaf remains in the base of many sand bodies of the Eslida Fm described above could be a response to these conditions.

\section{Discussion}

The study of the Eslida Fm illustrates the type of fluvial successions deposited in half-grabens during periods of rapid subsidence and abundant supply of sediment. The coarsening-thickening sequences resemble similar alluvial fan sequences but, instead of being the result of the progradation of proximal facies over distal facies (autocyclic process), corresponds to variable subsidence rates in the basin causing variable rates of creation of accommodation (allocyclic process).

Another point which is poorly understood in alluvial basins is the relationship of the fluvial sequences with the basement. The Eslida Fm provides an excellent example of an onlapping relationship, revealed by mapping and correlation of individual sequences. Progressive onlapping indicates that sedimentation rates kept pace with subsidence rates or were even higher, leading to an oversupply situation and the occupation of the available accommodation space.

In most rift basins, it is assumed that transverse drainage networks and alluvial fans along the basin boundary faults are a fundamental part of the depositional system and provide large amounts of sediment, but the Eslida Fm totally lacks this type of sediment, while the coeval Arandilla Fm only shows a very limited amount of alluvial fan deposits. This is probably due to a short period of accumulation, slow fault scarp retreat and lack of antecedent rivers cutting across the rift shoulders, an uncommon set of circumstances.

\section{Conclusions}

The main conclusions of this investigation are as follows:

(1) The Eslida Fm was deposited in the SE Iberian Basin, a half-graben with a major basin boundary fault dipping to the SW along its NE margin. This basin was axially interconnected with the Central Iberian Basin of half-graben geometry and opposite inclination.

(2) Six alluvial sequences were deposited according to an onlap relationship with the basement. The five lower ones of coarsening-thickening 
type correspond to periods of episodic vertical subsidence, while the sixth uppermost thickeningthinning sequence corresponds to the cessation of subsidence, lateral shifting and abandoning of the fluvial systems and the beginning of a major marine transgression.

(3) The active channel belt was preferentially located near the basin boundary fault where amalgamated sheet sandstone complexes developed. Away from the fault, overbank deposits are dominant, revealing asymmetric lateral infilling of the basin.

(4) The climate was seasonal with dry and humid periods permitting the partial preservation of feldspars and rock fragments.

(5) The main sediment source area was located to the NW along the axis of the basin. Minor source areas are found along the hanging-wall block to the $\mathbf{W}$.

\section{Acknowledgements}

We would like to thank Carlos Sánchez and Modesto Escudero for their help with illustrations, Mariano Marzo and Emilio Ramos for the calculation of subsidence curves and Gilberto Herrero for the thin sections of the rocks. We also thank Sierd Cloetingh and an anonymous referee for improving the manuscript with their comments. The English version of this paper was corrected by Ana Burton. This paper is a contribution to Projects PB 95-0084 and APC 97-0101, founded by the Spanish Ministry of Education and Culture.

\section{References}

Alexander, S., Leeder, M., 1987. Active tectonic control on alluvial architecture. SEPM Spec. Publ. 39, 243-252.

Allen, J.R.L., 1965. A review of the origin and characteristics of recent alluvial sediments. Sedimentology 5, 89-191.

Allen, J.R.L., 1970. Studies in fluviatile sedimentation: a comparison of fining-upward cyclothems, with a special reference to coarse-member composition and interpretation. J. Sediment. Petrol. 40, 298-323.

Allen, P.A., Hovius, N., 1998. Sediment supply from landslidedominated catchments: implications for basin-margin fans. Basin Res. 10, 19-36.
Allison, M.A., Kuehl, S.A., Martin, T.C., Hassan, A., 1998. Importance of floodplain sedimentation for river sediment budgets and terrigenous input to oceans: Insights from the Brahamaputra-Januma river. Geology 26, 175-178.

Alonso-Azcárate, J., Arche, A., Barrenechea, J., López-Gómez, J., Luque, F.J., Rodas, M., 1997. Paleogeographical significanœe of clay mineral assemblages in the Permian and Triassic sediments of the SE Iberian Ranges, eastern Spain. Palaeogeogr., Palaeoclimatol., Palaeoecol. 136, 309-330.

Arche, A., López-Gómez, J., 1996. Origin of the Permian-Triassic Iberian Basin, central-eastern Spain. Tectonophysics $266,443-464$

Bown, T.M., Kraus, M.J., 1987. Integration of channel and floodplain suites in aggrading fluvial systems. I. Developmental sequence and lateral relations of lower Eoœne alluvial paleosols, Willwood Fornation, Bighorn Basin, Wyoming. J. Sediment. Petrol. 57, 587-601.

Bridge, J., Leeder, M., 1979. A simulation model of alluvial stratigraphy. Sedimentology 26, 616-644.

Brierley, G.J., 1996. Channel morphology and element assemblages: a constructivist approach to facies modelling. In: Carling, P.A., Dawson, M.R. (Eds.), Advanees in Fluvial Dynamics and Stratigraphy. Wiley, New York, pp. 263-298.

Burbank, D.W., Leland, J., Fielding, E., Anderson, R.S., Brozoic, N., Reid, M.R., Duncan, C., 1996. Bedrock incision, rock uplift and thresold hillslopes in the Northeastern Himalayas. Nature 379, 505-510.

Calvache, M.L., Viseras, C., Fernández, J., 1997. Controls on fan development - evidence from fan morphology and sedimentology, Sierra Nevada, Spain. Geomorphology 21, $69-84$.

Cant, D., Walker, R.G., 1978. Fluvial processes and facies sequences in the sandy braided South Saskatchewan River, Canada. Sedimentology 25, 625-648.

Collinson, J.D., 1986. Alluvial sediments. In: Reading, H.G. (Ed.), Sedimentary Environments and Facies. Blackwell Scientific, Oxford, pp. 20-62.

Dalrymple, R.W., Makino, Y., 1989. Description and genesis of tidal bedding in the Cobequid Bay-Salmon River Estuary, Bay of Fundy, Canada. In: Taira, A., Masuda, F. (Eds.), Sedimentary Facies in the Active Plate Margin. Terra Sci. (Tokyo), 151-177.

Dickinson, W.R., 1985. Interpreting provenance relations from detrital models of sandstones. In: Zuffa, G.G. (Ed.), Provenance of Arenites. Reidel, Dordrecht, pp. 333-361.

Doubinger, J., López-Gómez, J., Arche, A., 1990. Pollen and spores from the Pernian and Triassic sediments of the Iberian Ranges, Cueva de Hierro (Cuenca) to Chelva-Manzanera (Valencia) region, Spain. Rev. Paleobot. Palynol. 6, $25-45$.

Dunne, T., Mertens, L.A.K., Meade, R.H., 1998. Exchange of sediment between the floodplain and channel of Amazon River in Brazil. Geol. Soc. Am. Bull. 110, 45-467.

Folk, R.L., 1974. Petrology of Sedimentary Rocks. Hemphill, Austin, TX. 159 pp.

Frostick, L., Reid, I., 1989. Climatic versus tectonic control of 
fan sequences: lesson from the Dead Sea, Israel. J. Geol. Soc. London 146, 527-538.

García-Royo, C., Arche, A., 1987. El Triásico de la región Nuévalos-Cubel (Zaragoza). Sedimentación en un sector del borde de cuenca del surco Molina-Valencia. Cuad. Geol. Iber. $11,575-606$.

Gradstein, F., Agterberg, F., @gg, J., Hardembol, J., Van Veen, P., Thierry, J., Huang, Z., 1995. A Triassic, Jurassic and Cretacous time scale. Geochronology Time Scales and Global Stratigraphic Correlation. SEPM Spec. Publ. 54, 95-126

Gutierrez, M., Sancho, C., Araujo, T., 1998. Scarp retreat rates in semiarid environments from talus flatirons, Ebro Basin, NE Spain. Geomorphology 25, 11-121.

Haszeldine, R.S., 1983. Fluvial bars reconstructed from a deep, straight channel, Upper Carbonif erous coalfield of northeast England. J. Sediment. Petrol. 53, 1233-1248.

Heller, P.L., Paola, C., 1992. The large-scale dynamics of grain size variation in alluvial basins. 2. Applications to syntectonic conglomerates. Basin Res. 4, 91-102.

Heller, P.L., Paola, C., 1996. Downstream changes in alluvial architecture: an exploration of controls on channel-stacking patterns. J. Sediment. Res. 66, 297-306.

Heward, A.P., 1978. Alluvial fans and lacustrine sediments from the Stephanian A and B (La Magdalena, Ciñera-Matañana and Sabero) coalfields, Northern Spain. Sedimentology 25 , 451-488.

Jackson, R.G., 1981. Sedimentology of muddy fine-grained channel deposits in meandering streams of the American Middle West. J. Sediment. Petrol. 51, 1169-1192.

Kirk, M., 1983. Bar developments in a fluvial sandstone (Westphalian 'A'), Scotland. Sedimentology 30, 727-742.

Kirschbaum, M.A., McCabe, P.J., 1992. Controls on the accumulation of coal and on the development of anastomosed fluvial systems in the Cretaceous Dakota Formation of southern Utah. Sedimentology 39, 581-598.

Kooi, H., Beaumont, C., 1996. Large scale geomorphology: classical concepts reconciled and integrated with contemporary ideas via a surface processes model. J. Geophys. Res. 101, 3361-3386.

Kutzbach, J.E., Guetter, P.J., Washington, W.M., 1990. Simulated circulation of an idealized aeean from Pangean time. Paleoceanography 5, 299-317.

Leeder, M., 1973. Fluviatile fining-upward cycles and the magnitude of paleochannels. Geol. Mag. 110, 265-276.

Leeder, M., 1978. A quantitative model for alluvium. Can. Soc. Petrol. Geol. Mem. 5, 587-596.

Leeder, M., 1997. Sedimentary basins: tectonic recorders of sediment discharge from drainage catchments. Earth Surf. Proc. Land. 22, 229-237.

Lewin, J., 1978. Floodplain geomorphology. Progr. Phys. Geogr. 2, 408-437.

López-Gómez, J., Arche, A., 1993a. Sequenee stratigraphic analysis and paleogeographic interpretation of the Buntsandstein and Muschelkalk facies (Pernian-Triassic) in the SE Iberian Ranges, E. Spain. Palaeogeogr., Palaeoclimatol., Palaeoecol. 103, 179-201.
López-Gómez, J, Arche, A., 1993b. Architecture of the El Cañizar fluvial sheet sandstone, Early Triassic, Iberian Ranges, eastern Spain. In: Marzo, M., Puigdefábregas, C. (Eds.), Alluvial Sedimentation. Int. Assoc. Sediment. Spec. Publ. 17, 363-381.

López-Gómez, J., Arche, A., 1994. La Formación Brechas de Tabarreña (Pérmico Inferior): Depósitos de flujos con densidad variable al SE de la Cordillera Ibérica, España. Bol. R Soc. Esp. Hist. Nat. (Sec. Geol.) 89, 131-144

Márquez, L., López-Gómez, J., Trifonova, E., 1994. Datación (foraminíferos) y ambientes sedimentarios de la Fonnación Dolomías de Landete, Anisiense, Facies Muschelkalk, provincia de Cuenca. Bol. R. Soc. Esp. Hist. Nat. (Sec. Geol.) 89, 99-107.

McCarthy, P., Plint, A., 1998. Recognition of interfluve sequence boundaries: integrating paleopedology and sequence stratigraphy. Geology 26, 387-390.

Mertens, L.A.K., 1994. Rates of floodplain sedimentation on the central Amazon river. Geology 22, 171-174.

Miall, A.D., 1996. The Geology of Fluvial Deposits. Springer, Berlin, $582 \mathrm{pp}$.

Morison, S.R., Hein, F.J., 1987. Sedimentology of the White Channel gravels, Klondike area, Yukon Territory: fluvial deposits of a confined valley. In: Ethridge, F.G., Flores, R.M., Harvey, M.D. (Eds.), Recent Developments in Fluvial Sedimentology, Soc. Econ. Paleontol. Mineral. Spec Publ. 39, 205-216

Muñoz, A., Ramos, A., Sopeña, A., Sánchez-Moya, Y., 1995. Caracterización de las unidades litoestratigráficas del Triásico en el subsuelo del tercio noroccidental de la Cordillera Ibérica y zonas adyaœntes. Cuad. Geol. Iber. 19, 129-171.

Nombela, M.A., Vilas, F., Evans, G., 1995. Sedimentation in the mesotidal Rias Bajas of Galicia (north-western Spain) Ensenada de San Simón, inner Ria de Vigo. In: Flemming, B.W., Bartholomä, A. (Eds.), Tidal Signatures in Modern and Ancient Sediments. Int. Assoc. Sediment. Spec. Publ $24,133-150$.

Pérez-Arlucea, M., 1987. Distribución paleogeográfica de las unidades lel Pérmico y Triásico en el sector Molina de Aragón-Albarracín. Cuad. Geol. Iber. 11, 607-622.

Pérez-Arlucea, M., Sopeña, A., 1985. Estratigrafía del Pérnnico y Triásico en el sector entral de la rama Castellana de la Cordillera Ibérica (Provincias de Guadalajara y Teruel) Estud. Geol. 41, 207-222.

Puigdefábregas, C., 1973. Miocene point-bar deposits in the Ebro Basin, northern Spain. Sedimentology 20, 133-144.

Ramos, A., 1979. Estratigrafía y paleogeografía del Pémnico y Triásico al oeste de Molina de Aragón (Guadalajara). Sem. Estratigr., Ser. Monograf. 6303 pp.

Richards, K.S., 1986. Fluvial geomorphology. Progr. Phys. Geogr. 10, 401-420

Rosendahl, B.R., Reynolds, D.J., Lorber, P.M., Burgess, C.F., 1986. Structural expressions of rifting: lessons from Lake Tanganyika, Africa. Geol. Soc. London Spec. Publ. 25, $29-43$.

Rust, B., 1981. Sedimentation in an arid-zone anastomosing 
fluvial system: Cooper's Creek, central Australia. J. Sediment. Petrol. 51, 745-755.

Smith, N.D., 1971. Transverse bars and braiding in the lower Platte River, Nebraska. Geol. Soc. Am. Bull. 82, 3407-3420.

Smith, D.G., Smith, N.D., 1980. Sedimentation in anastomosed river systems: examples from alluvial valleys near Banff, Alberta. J. Sediment. Petrol. 50, 157-164.

Smith, N.D., Cross, T.A., Duffey, J.P., Clough, S.R., 1989. Anatomy of an avulsion. Sedimentology 36, 1-24.

Sopeña, A., Doubinger, J., Ramos, A., Pérez-Arlucea, M., 1995. Palynologie du Permian et $\mathbf{d u}$ Trias dans le centre de la Peninsule Ibérique. Sci. Géol. Bull. 48, 119-159.

Sopeña, A., López-Gómez, J., Arche, A., Pérez-Arlucea, M., Ramos, A., Virgili, C., Hernándo, S., 1988. Permian and Triassic of the Iberian Peninsula. In: Manspeizer, W. (Ed.), Triassic-Jurassic Rifting - Continental Breakup and the Origin of the Atlantic Acean and Passive Margins. Developments in Geotectonics Vol. 22B. Elsevier, Amsterdam, pp. 757-786.

Summerfield, M.A., Hulton, N.J., 1994. Natural controls on fluvial denudation rates in major world drainage basins. J. Geophys. Res. 99, 13 871-13883.

Tucker, M., 1991. Sedimentary Petrology. second ed., Blackwells, Oxford, $260 \mathrm{pp}$.
Vergés, J., Lewis, C., Marzo, M., 1996. Drenaje fluvial y topografia ligados a la extensión: NE de Iberia. Geogaeta 20, $850-852$.

Walling, D.E., Webb, B.W., 1983. Patterns of sediments yield. In: Gregory, K.J. (Ed.), Background to Paleohydrology. Wiley, Chichester, pp. 69-100.

Walker, R.G., Cant, D.J., 1979. Sandy fluvial systems. In: Walker, R.G. (Ed.), Facies Models. Geosci. Can. Repr. Ser. $1,23-31$.

Yerino, L.N., Maynard, J.B., 1984. Petrography of modern marine sands from the Peru-Chile trench and adjacent areas. Sedimentology 31, 83-89.

Ziegler, P.A., 1988. Post-Hercynian plate reorganization in the Tethys and Artic-North Atlantic domains. In: Manspeizer, W. (Ed.), Triassic-Jurassic Rifting. Continental Breakup and the Origin of the Atlantic Ocean and Passive Margins. Developments in Geotectonics Vol. 22B. Elsevier, Amsterdam, pp. 712-756

Ziegler, A.M., Bambach, R.K., Parrish, J.T., Barrett, S.F., Gierlowski, E.H., Parker, W.C., Raymond, A., Sepkowski Jr, J.J., 1981. Paleozoic biogeography and climatology. In: Niklas, K.J. (Ed.), Paleobotany, Paleoecology and Evolution Vol. 2. Praeger, New York, pp. 231-261. 